\title{
On BCG Vaccine Protection from COVID-19: A Review
}

\author{
Narges Bagheri ${ }^{1,2} \cdot$ Hesam Montazeri ${ }^{2}$ \\ Accepted: 21 February 2021 / Published online: 15 March 2021 \\ (C) The Author(s), under exclusive licence to Springer Nature Switzerland AG part of Springer Nature 2021
}

\begin{abstract}
Bacille Calmette-Guérin (BCG) vaccine has been globally used to protect infants against tuberculosis (TB) for about a century. This vaccine has been shown to provide some degree of non-specific protection from other respiratory tract infections. This advantage has encouraged researchers to investigate the potential protection of this vaccine from the coronavirus disease 2019 from different perspectives in the ongoing pandemic. In this study, we have comprehensively reviewed the latest articles on potential vaccine effectiveness of BCG on COVID-19 and summarized the possible impacts of the BCG against SARS-COV-2 in detail.
\end{abstract}

Keywords BCG vaccine $\cdot$ COVID-19 $\cdot$ Non-specific vaccine protection $\cdot$ Tuberculosis

\section{Introduction}

The SARS-COV-2 pandemic started in Wuhan, China, in December 2019 and quickly spread to other areas of china and other countries. While a large fraction of COVID-19 patients remains asymptomatic or suffers from mild to moderate symptoms [1], some patients progress to serious pneumonia, respiratory insufficiency, and even death, particularly in old and comorbid patients [2]. In contrast, many studies have reported that children often experience mild symptoms [3, 4].

The causes of mild COVID-19 infections in children is not completely understood. A plausible explanation for mild COVID-19 diseases in children can be variations in the expression of the angiotensin-converting enzyme 2 receptors (ACE2 receptor) which is essential for the SARS-COV-2 to bind and make the infection [5]. Another possibility is immunity obtained from recommended childhood vaccinations. However, it is noteworthy to state that the mechanism of the acquired immunity is not completely understood as many patients cured of COVID-19 have subsequently re-contracted the virus $[6,7]$.

This article is part of the Topical Collection on Covid-19

Hesam Montazeri

hesam.montazeri@ut.ac.ir

1 Department of Applied Mathematics, University of Azarbaijan Shahid Madani, Tabriz, Iran

2 Department of Bioinformatics, Institute of Biochemistry and Biophysics (IBB), University of Tehran, Tehran, Iran
Bacillus Calmette-Guérin is one of the childhood vaccinations mainly used to prevent the spread of tuberculosis (TB) and tuberculous meningitis. TB is a bacterial airborne infectious disease caused by Mycobacterium tuberculosis. In general, tuberculosis is a lung pathogen, but it can affect any other parts of the body as well. TB infections can be categorized into two groups. The first type, called latent TB infection (LTB), does not have any symptoms and is non-transmissible. In the second type of TB infection, patients suffer from an active TB disease with symptoms such as fever, fatigue, lack of appetite, and weight loss generally. Persistent cough and hemoptysis can occur in advanced pulmonary diseases. Transmissible or active TB disease is diagnosed with culture-based or molecular diagnostics [8].

The biological effect of vitamin $\mathrm{D}$ in immunity against $\mathrm{TB}$ has been increased the researchers' interests in this field. Vitamin D can have a role in immune regulation. This vitamin can be effective in many autoimmune and inflammatory disease [9]. In 2011, one study was performed to assess whether there was a correlation between circulating $25(\mathrm{OH}) \mathrm{D}$ concentration and the status of BCG vaccination and cytokine response after $B C G$ vaccination. The findings have shown that vaccination of BCG affects the concentration of vitamin D [10]. Moreover, according to available literature, BCG stimulates the immune system of human against many forms of viruses (e.g., human papillomavirus and human respiratory syncytial virus) [11]. These advantages of the BCG vaccine creates the temptation that BCG may prevent COVID-19 deaths or severity.

Recently, some epidemiological studies were performed to investigate the effect of BCG vaccination against COVID-19 infection. Several studies have shown that countries with 
universal BCG vaccination policies appear to be less affected by the pandemic $[12,13]$. However, some other studies argue that there cannot be an essential correlation between $\mathrm{BCG}$ vaccinations and the rate of mortality caused by COVID-19 $[14,15]$. Most of these studies are based on statistical analysis of observational data. While such findings are helpful in providing some degree of insight into the association between BCG vaccine and COVID-19, they have shortcomings as well. There are a variety of confounding variables that should be accounted for, as noted by the authors of all these studies. Currently, this hypothesis is testing by clinical trials to adjust confounders. These trials are conducted in countries with different BCG vaccination policies. This study aimed to review and evaluate the studies on the probable effect of BCG on the severity of cases in patients with COVID-19.

\section{BCG Vaccination in Various Diseases}

For around 100 years, the BCG vaccine with protective effects against TB has been the most popular vaccine used worldwide. This vaccine has heterologous protective effect against unrelated diseases. Experts propose two main types of immunological mechanisms of such effects. In the first type called heterologous immunity, memory cells of CD4 and CD8 can be stimulated in antigen-independent ways, for instants by cytokines activated by secondary infections [16]. In the second type, vaccination of BCG causes histone modifications and epigenetic reprogramming of human monocytes. This process leads to a more active innate immune response known as trained immunity $[17,18]$. Several important molecular aspects of trained innate immunity against COVID-19 have been discussed in [19].

Tuberculosis The efficacy of the BCG vaccination in protection against serious, extra pulmonary types of active TB was found to be 50 to $80 \%$ in case-control studies among infants and children under 5 years old [20]. Furthermore, immunity from TB infection has also been correlated with BCG vaccination in children [21]. An interesting case of co-infection of TB pneumonia and COVID-19 has been discussed in [22].

Sepsis In a clinical study, performed in West Africa, after receiving early $\mathrm{BCG}$ vaccination, the rate of mortality infants with low birth weight due to neonatal respiratory sepsis, experienced a reduction by $17 \%$ in comparison to the delayed vaccinated [23]. In 2012, another clinical trial compared vaccinated and control groups and reported that BCG vaccination can lead to decrease the mortality due to lower respiratory sepsis/pneumonia fatalities [24].

Influenza A randomized clinical trial (RCT) regarding the vaccine strain of H1N1 influenza concluded that when healthy volunteers are vaccinated with BCG vaccine before receiving the influenza vaccine, the induction of their functional antibody response is increased [25].

Yellow Fever Arts et al. recently stated that BCG vaccination, by epigenetic reprogramming in circulating monocytes, protects adults against the yellow fever virus vaccine strain. Furthermore, the study argued that BCG vaccination resulted in the induction of trained immunity shown by an upregulation of IL-1 $\beta$-mediated responses that linked to a reduction in viral load. As a result, vaccinated participants are protected compared to the control group [26].

Cancer The report on a 60-year follow-up of early BCGvaccinated American Indian and Alaska Native populations indicated that lung cancer was substantially less prevalent among those receiving BCG vaccine than placebo. No significant difference was found in other cancer rates. In this clinical trial, the reported reduction in lung cancer was not correlated with previous TB infection. The mechanism of this protective observation is unclear, but the author has offered trained immunity as a hypothesis [27]. Furthermore, BCG immunotherapy is often used as the standard therapy for the treatment of patients with high-risk non-musical-invasive bladder cancer to prevent the disease from recurring and progressing [28].

Diabetes BCG vaccine is emerging as an important treatment for autoimmune disorders. In type 1 diabetics, individuals treated with two BCG vaccines reported a decrease in blood sugar levels to near-normal levels after a delayed period of time in an 8-year clinical trial [29].

COVID-19 is a respiratory tract viral infection caused by SARS-CoV-2. The symptoms of this infection are different among individuals and different age groups. The following symptoms are commonly reported symptoms: cough, shortness of breath or difficulty breathing, fever, fatigue or weakness, muscle or body pains, loss of smell or taste, headache, and gastrointestinal symptoms [30]. There are several clinical and epidemiological features common between TB and COVID-19. Both mainly attack the lungs and there are common clinical symptoms such as cough, fever, and shortness of breath in patients. Two infections are caused by respiratory airborne (aerosol) route or droplets. Both are transmitted through the air and close contacts. Diabetes, immune suppression, old age, and chronic obstructive pulmonary disease are among the risk factors of either disease. In addition, more men than women are affected by COVID-19 and TB. The possibility of protection against COVID-19 through BCG vaccination is an important public health question.

\section{BCG Revaccination}

Revaccination with live vaccine including BCG may increase the benefits of non-specific effects (NSEs) against disease risk 
and mortality [31]. The most plausible reason for the beneficial NSEs of live vaccine revaccination is that the immunizing antigen shapes complexes of antibodies existing priory and defines a beneficial non-specific immune response that offers defense against a number of infectious diseases [31]. The capacity of BCG to cause heterologous immunomodulatory effects on unrelated conditions is well known. Increased internalization of BCG into monocytes, increased NOD2 activation and NO output, mediating even stronger epigenetic effects, resulting in increased trained innate immunity, could be the beneficial effect of BCG revaccination. Notably, BCG immunotherapy results against bladder cancer are better and more effective in patients who have received the $B C G$ vaccine before to the start of treatment [32].

\section{Efficacy of BCG Revaccination Against TB}

To improve the duration of protection a booster dose of BCG can be considered. However, in February 2018, based on converging pieces of evidence that $\mathrm{BCG}$ revaccination provides no additional protection from TB, WHO stated that repeat vaccination is not recommended for people who have received BCG vaccination because scientific data does not support it [33]. Since then, at least one study, on the contrary, suggest the benefits of repeating BCG vaccination against TB [34].

\section{Impact of BCG Revaccination on Overall Mortality Rate}

One study conducted in Guinea-Bissau indicated a 50\% reduction in overall deaths among children who received the $\mathrm{BCG}$ vaccine. This reduction was attributed to the impact of the vaccine on the reduction of respiratory infections and sepsis [35]. Recently, a BCG revaccination trial was carried out in Bissau to assess whether repeat vaccination of BCG at age of 19 months decreases overall mortality rates. Because of several deaths in the vaccination arm, this trial was stopped before the determined end point; these deaths occurred at the time when children received the missing vaccine, iron supplements, or vitamin A. During the trial, the impact of BCG on mortality in children who received the diphtheria-tetanuspertussis (DTP) booster vaccine before registration and those who had not was significantly different. Finally, the authors concluded that there was no benefit in BCG revaccination [36]. Nonetheless, the review of the literature for the BCG, $\mathrm{MV}, \mathrm{OPV}$, and smallpox revaccination studies was associated with a significant reduction in overall mortality comparison with just one dose [31].

\section{Impact of BCG Revaccination on Safety}

The rates of adverse reactions to the first and second doses of $B C G$ vaccination were evaluated from the findings of a large population trial carried out in Brazilian children aged 7 to 14 years. Although reaction to the second dose was more frequent than first BCG vaccinations (23 adverse reactions observed among people with the scar and two adverse reactions observed among people without any scar), it was not statistically significant. The author concluded that there is insufficient safety data, but based on results, the adverse reactions to the second dose of BCG are uncommon [37].

Recently in the phase 3 of a double-blind, active randomized trial, it has been done to determine the potential of BCG vaccine for protecting the adult patients from infections, particularly respiratory infections. Outcomes demonstrate that vaccination of BCG is safe and it can reduce the number of infections in elderly at-risk population. Moreover, people in the treatment group took longer to occur the first infection in comparison with the placebo arm (16 weeks among vaccinated people and 11 weeks among unvaccinated people). The researchers did not found any significant difference between two groups in terms of adverse effects. Consequently, they concluded that BCG vaccination was safe among adult patients. The vaccine may also protect the adults from COVID-19, but this has not been thoroughly tested so far [38].

\section{Investigations of BCG and COVID}

This section reviews three different groups of epidemiological studies assessing the effects of BCG vaccination on COVID19: (a) comparison of countries with and without vaccination policy, (b) analysis of countries with discontinued vaccinations, and (c) analysis of subgroups.

\section{Comparison of Countries With or Without Vaccination Policy}

Table 1 shows a summary of studies that compare countries with and without nation-wide vaccination policy. In particular, they evaluate incidence or mortality rates of COVID-19 in countries with current vaccine program for BCG versus countries that never have had BCG vaccination and/or countries that have stopped this vaccination (Fig. 1). Most studies assess how BCG vaccinations can affect cases and/or mortality in the ongoing pandemic mainly using regression models. Although the data are collected from public resources in all of the studies, the conclusions are contradictory among various studies. As can be seen in Table 1, authors in six studies argued that the BCG vaccination policy may not be effective while seven studies indicated the BCG can reduce the severity of the disease.

The analyses can be influenced by some reporting biases such as the accessibility to diagnostic testing. These problems were mitigated in three ways by Berg et al. [42]. First, the growth rate of confirmed cases and mortality were used for a 
Table 1 Summary of epidemiology studies assessing the effect of BCG on COVID-19 in countries with or without nation-wide vaccination policy

\begin{tabular}{|c|c|c|c|c|}
\hline Author/year & \#Countries & $\begin{array}{l}\text { Confounders or predictors/dependent } \\
\text { variable }\end{array}$ & Method & Findings \\
\hline $\begin{array}{c}\text { Escobar et al. } \\
2020[13]\end{array}$ & 22 countries & $\begin{array}{l}\text { At least one death per million } \\
\text { inhabitants, } \geq 15 \% \text { of population with } \\
\text { an age of } 65 \text { years or more, }>60 \% \text { of } \\
\text { population living in urban areas, }< \\
300 \text { inhabitants } \mathrm{km}^{2}, \text { and an HDI of }> \\
0.7 / \text { mean, median, and maximum } \\
\text { deaths per million }\end{array}$ & $\begin{array}{l}\text { ANOVA, } t \text { test, linear } \\
\text { regression }\end{array}$ & BCG could have a protective effect \\
\hline $\begin{array}{l}\text { Wickramasinghe } \\
\text { et al. } 2020 \\
\text { [39] }\end{array}$ & 175 countries & $\begin{array}{l}\text { Demographic variables, BCG coverage } \\
\text { and policy, age-specific TB incidence, } \\
\text { and income level/morbidity and mor- } \\
\text { tality of COVID-19 }\end{array}$ & Linear regression analysis & $\begin{array}{l}\text { Immunity from BCG as a likely } \\
\text { explanation for the variation of } \\
\text { COVID-19 cases and deaths across } \\
\text { countries }\end{array}$ \\
\hline $\begin{array}{l}\text { Kumar et al. } \\
2020[40]\end{array}$ & 67 countries & $\begin{array}{l}\text { Temperature and BCG } \\
\text { vaccination/number of new cases and } \\
\text { mortality per day }\end{array}$ & $\begin{array}{l}\text { Multivariable two-level } \\
\text { negative binomial regres- } \\
\text { sion analysis }\end{array}$ & $\begin{array}{l}\text { High temperature might not be } \\
\text { associated with low transmissibility } \\
\text { and BCG vaccination had a low } \\
\text { fatality rate of COVID-19 }\end{array}$ \\
\hline $\begin{array}{c}\text { Klinger et al. } \\
2020[41]\end{array}$ & 55 countries & $\begin{array}{l}\text { Economic, demographic, health-related, } \\
\text { and pandemic restriction related } \\
\text { quantitative properties/death per } \\
\text { million, positively validated cases per } \\
\text { million, hospitalization with serious } \\
\text { and critical conditions, and recovered }\end{array}$ & Multivariable regression & $\begin{array}{l}\text { BCG immunization coverage, esp. } \\
\text { among the most recently vaccinated } \\
\text { population, contribute to attenuation } \\
\text { of the spread and severity of the } \\
\text { COVID-19 }\end{array}$ \\
\hline $\begin{array}{l}\text { Berg et al. } 2020 \\
\text { [42] }\end{array}$ & $\begin{array}{l}\text { Confirmed } \\
\text { cases }(134 \\
\text { countries }) \\
\text { and deaths } \\
\text { (135 } \\
\text { countries) }\end{array}$ & $\begin{array}{l}\text { Median age, gross domestic product per } \\
\text { capita, population density, population } \\
\text { size, net migration rate, and various } \\
\text { cultural dimensions/the number of } \\
\text { cases and deaths }\end{array}$ & $\begin{array}{l}\text { Linear mixed effect models } \\
\text { with restricted maximum } \\
\text { likelihood estimation }\end{array}$ & $\begin{array}{l}\text { Mandated BCG vaccination can be } \\
\text { effective against COVID-19 }\end{array}$ \\
\hline $\begin{array}{l}\text { Joy et al. } 2020 \\
\text { [43] }\end{array}$ & 160 countries & $\begin{array}{l}\text { Population density, income group, } \\
\text { latitude, and percentage of the total } \\
\text { population under age groups 15-64 } \\
\text { and above } 65 \text { years of each } \\
\text { country/the difference in the incidence } \\
\text { of COVID- } 19 \text { cases }\end{array}$ & Meta-regression & $\begin{array}{l}\text { BCG is associated with reduced } \\
\text { COVID-19 infections if the BCG } \\
\text { vaccine coverage }>70 \%\end{array}$ \\
\hline $\begin{array}{l}\text { Miller et al. } 2020 \\
\text { [44] }\end{array}$ & 60 countries & $\begin{array}{l}\text { Age distribution, income per capita, } \\
\text { stage of the epidemic of a country, and } \\
\text { quality of the medical care country's } \\
\text { response to COVID-19/morbidity and } \\
\text { mortality for COVID-19 }\end{array}$ & Multivariate linear analyses & $\begin{array}{l}\text { BCG vaccination is correlated with } \\
\text { reduced mortality (from May 5th, } \\
\text { there is no significant correlation } \\
\text { between start year of the vaccination } \\
\text { and mortality per million people }<65 \\
\text { years) }\end{array}$ \\
\hline $\begin{array}{r}\text { Szigeti et al, } \\
2020[45]\end{array}$ & $\begin{array}{l}\text { The top } 68 \\
\text { countries for }\end{array}$ & $\begin{array}{l}\text { BCG vaccination status before } 1980 \text {, } \\
\text { historic colonization status, median }\end{array}$ & $\begin{array}{l}\text { Multiple regression } \\
\text { modeling }\end{array}$ & $\begin{array}{l}\text { No significant association between } \mathrm{BCG} \\
\text { vaccination and COVID-19 mortality }\end{array}$ \\
\hline
\end{tabular}
number of age, urban population percentage, cases population density, tests per million (additional factor for May), and air passengers/deaths per million

Wassenaar et al. 18 countries Countries that are well into the 2020 [46] developing pandemic and compared the BCG vaccination programs in place since the $1950 \mathrm{~s}$

Hensel et al. [47] 74 countries GDP, median age, percent urban population, hospital beds per 1000 inhabitants, smoking, population density, diabetes and CVD-related deaths, vaccine strain, and testing rates/spread and mortality of $\mathrm{CoV}-2$

Matsuura et al. 17 countries
$2020[48]$

Multiple regression

Univariate and multivariate regression

Regression discontinuity analysis (on some countries) and difference-in-difference analysis (all countries)
There is currently no compelling evidence of protective effect

epidemiological findings do not provide evidence to correlate overall $\mathrm{BCG}$ vaccination with the spread and mortality of CoV-2

The results do not support this hypothesis that BCG can be effective 
Table 1 (continued)

\begin{tabular}{|c|c|c|c|c|}
\hline Author/year & \#Countries & $\begin{array}{l}\text { Confounders or predictors/dependent } \\
\text { variable }\end{array}$ & Method & Findings \\
\hline $\begin{array}{l}\text { Arlehamn et al. } \\
2020[14]\end{array}$ & 51 countries, & $\begin{array}{l}\text { Human Development } \\
\text { Index of }>0.7,>60 \% \text { urban population, } \\
\quad<300 \\
\text { Inhabitants per km } \mathrm{km}^{2} \text {, and }>1 \text { COVID-19 } \\
\quad \text { death per million/death report }\end{array}$ & $\begin{array}{l}\text { Pearson correlation } \\
\text { coefficient }\end{array}$ & $\begin{array}{l}\text { Current mortality rates of the COVID-19 } \\
\text { do not support a clear negative corre- } \\
\text { lation with BCG }\end{array}$ \\
\hline
\end{tabular}

short period. Second, the best available estimate of countrywise reporting biases was utilized as a weight in their study. Third, the availability of testing was controlled. To control confounding factors, the analysis included total population, the median age of them, and population density as demographic variables. Furthermore, net migration as individuals entering the country minus those leaving the country in per 1000 population and GDP per capita was used to control population movement and economic development respectively. Countries were weighted based on the accuracy of the reports to account for underreporting of cases. The total number of tests were controlled in countries to address the difference in number of tests. Two cultural aspects were assessed as possible confounding variables: individualism versus collectivism and power distance. They found that BCG vaccination may be efficient against the spread of COVID-19.

The possibility of an existing relationship between BCG vaccines and COVID-19 disease were analyzed by Escobar et al. through study of countries with different vaccination policy, European countries including Germany, and the
USA. COVID-19 mortality data were collected due to more possibility that the number of deaths can be more accurate than the number of cases and social variables were considered as the possible confounders. The assessment was adjusted for possible confounding variables such as the Human Development Index (HDI of $>0.7)$, human density $(<300$ inhabitants each square kilometer), urbanization ( $>60 \%$ of the people living in urban regions), and the age structure of the population $(\geq 15 \%$ of the people with 65 years old or more). Although the control of confounders reduced the BCG significant effect, there was still a significant association between BCG vaccination and COVID-19. The pandemic of COVID-19 entered the USA by air traffic. They compared COVID-19 mortality in non-BCG vaccination states in the USA with those that were the main entry points in Mexico and Brazil. The results indicated that COVID-19 mortality was higher in the USA [13].

The spread rate of COVID-19 was analyzed in 74 countries where stratified on the basis of BCG vaccination coverage. At first, a negative correlation was observed between the BCG

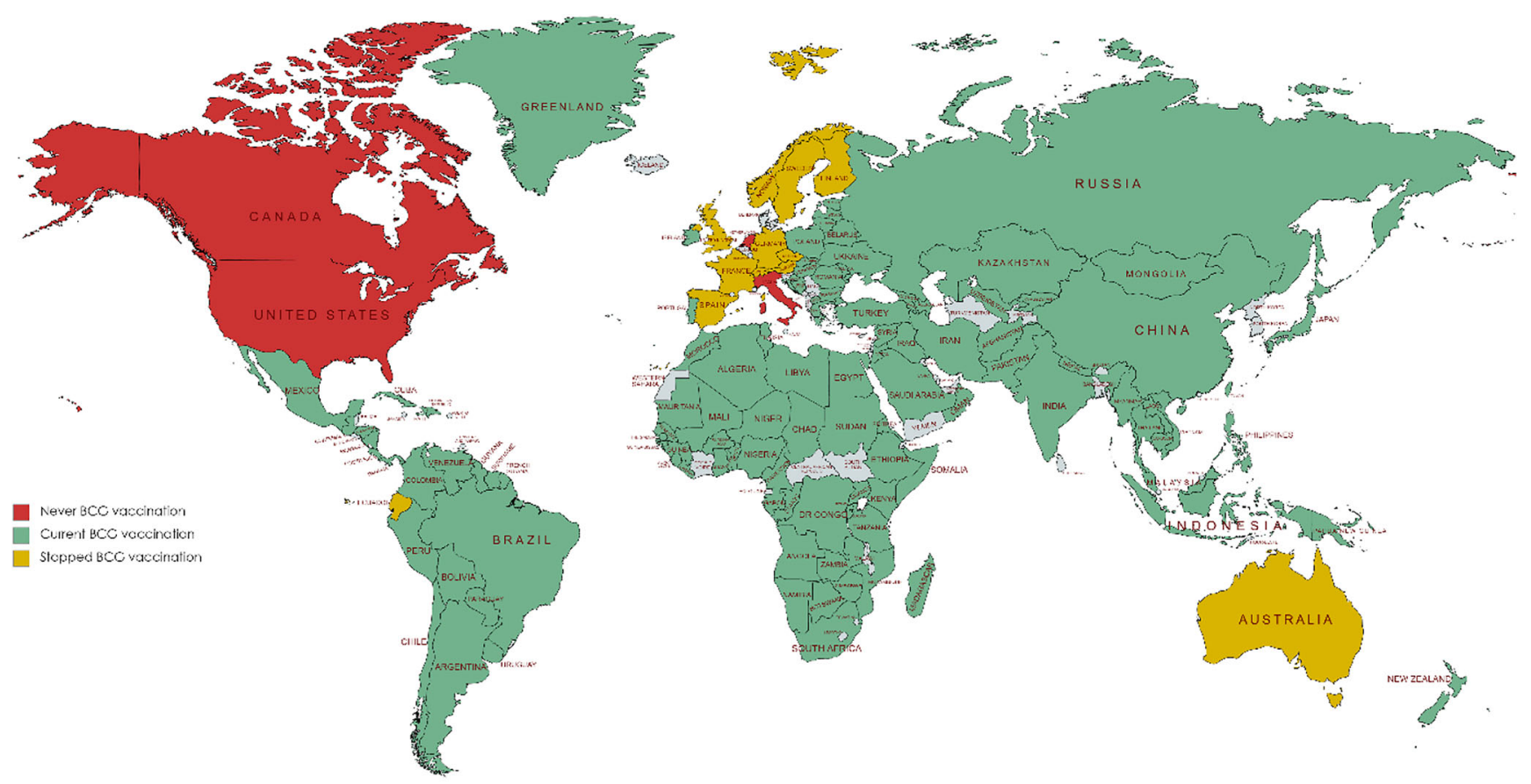

Fig. 1 The Status of BCP vaccination policy in the world[49] 
vaccination and the spread of COVID-19 as well as its mortality. Univariate analysis, however, revealed that age can be confounder variable in the analysis. When the age was adjusted, there was not such a difference, although age remained statistically linked to mortality rate. Since testing rates were significantly correlated with SARS-CoV-2 infection incidence, countries with high SARS-CoV-2 testing rates (10 or more tests per thousand) were analyzed. The findings indicated a lack of significant differences in the spread rate of SARS$\mathrm{CoV}-2$ in countries with different $\mathrm{BCG}$ vaccination policies. When countries were stratified based on the strain of vaccine, there was not higher mortality rate related to COVID-19. However, it might be due to small sample size (44 countries). They concluded that there is some evidence that SARS CoV-2 testing rate is an important confounder in the correlation between BCG vaccination and spread rate of SARS CoV-2. Some limitations such as difference in the strains of $\mathrm{CoV}-2$ virus, other co-morbidities (e.g., cancer and obesity), misreporting in positive case were mentioned by authors [47].

In another study, Kumar et al. assumed BCG vaccinations and temperature as predictor variables for both the newly diagnosed cases and death rates per day. As the number of new infections and deaths counted daily (outcome variables) are non-negative discrete numbers, they used Poisson regression. A non-linear transmission pattern between temperature and COVID-19 was seen. The result indicated that the lower temp is the most practical range for transmitting. The countries with the highest incidence rate had the median temp varied from 6 to $10.5{ }^{\circ} \mathrm{C}$. However, any statistically significant association between median temp and the transmission of the virus was not observed. Nonetheless, the rate of spreading was significantly less in countries with the policy of BCG vaccination. In their study, the number of tests adjusted but other potential confounder variables such as variations in the national demographics, risk of infection and the level of the outbreak for different countries did not adjust [40].

There was no significant negative correlation between BGG and COVID-19 deaths in the updated data on 1 August 2020 [14]. In an independent study, Miller et al. also found there is no significant association between the BCG vaccinations and coronavirus mortality rate among adults older than 65 years by analyzing the data after 5 May 2020 . However, using data from 21 March 2020, there was a significant association between mortality of COVID-19 and the time when the vaccination of BCG was started. The earlier responses to the infection were attributed to intrinsic immunity of elder people to disease. Their study covers countries with a population of more than one million. Since several factors, such as the economics of a country and the distribution of population age, may influence the measure of deaths, three groups of countries were considered to account for economic aspects: low-income, lower-middle, and countries with middle-high or high-income. To determine the mortality rate, the total number of inhabitants were not chosen, but the susceptible people over 65 years old were listed in every country. While countries have been stratified and those countries whose income level are middle-high and high are evaluated, inequalities in health systems, the quality in public healthcare services in addressing to the infection, and poverty rates may be unresolved confounders. Multivariate linear regression analysis was the approach used to adjust these confounders. In order to address tend of assigning COVID-19 deaths to other causes, they used European countries as a smaller dataset [44].

In comparison to Miller, et al. [44], countries with a population of less than 1 million were not excluded in the study of Szigeti et al. [45]. Authors argue that smaller countries such as Iceland may have better universal testing strategies. Instead, they analyzed the 68 countries that have most numbers of cases on April 3rd including the Diamond Princess Cruise ship as 68th. With the April 3th dataset, two multiple regression models were fitted using mortality rate as a dependent variable for each model, respectively, and the status of BCG vaccinations before 1980, median age, the status of historic colonization, the density of population, percentage of the urban population, and air travelers were considered as independent variables. These analyses were repeated using May 15th dataset and an additional independent variable namely tests/ million was considered. Finally, they found no significant association between BCG vaccinations and mortality from COVID-19 across countries.

Klinger et al. considered two types of vaccination: (1) countries with existing or previous BCG vaccination policies, (2) countries that have provided it for a specific at-risk group. Results from multivariate regression tests with predictors such as economic (indicators of economic development), healthrelated (prevalence of chronic diseases such as type 2 diabetes and mortality rate of cardiovascular disorder), and quantitative properties related to the restriction of pandemic (school closure and educational management) validated the role of BCG against COVID-19 infection [41].

\section{Analysis of Countries with Discontinued Vaccination}

The mandatory BCG vaccination policy has been stopped in some countries where the incidence of TB declined. In Table 2, the incidence rates of COVID-10 in vaccinated and unvaccinated subpopulation of these countries were compared. Germany is a prominent example to examine the possible impact of the age of BCG vaccinations on COVID-19 susceptibility, as vaccination schemes were different before the unification of East and West Germany [13]. In East Germany, BCG vaccination became mandatory in 1953. By contrast, this vaccination was much less common in West Germany (recommended since 1955) and it was stopped completely between 1975 and 1977. As is shown in Table 2 
Table 2 summary of assessing the impact of BCG vaccination in countries having discontinued the BCG vaccination policy

\begin{tabular}{|c|c|c|c|}
\hline Author/year & Method & Study case (country) & Findings \\
\hline $\begin{array}{l}\text { de Chaisemartin, C. } \\
\text { and L. de Chaisemartin, } \\
2020[51]\end{array}$ & Regression discontinuity (RD) & $\begin{array}{l}\text { Compare the number of COVID-19 } \\
\text { cases, hospitalizations, and deaths } \\
\text { among individuals born just before } \\
\text { and just after } 1 \text { April } 1975 \text { (Sweden) }\end{array}$ & $\begin{array}{l}\text { Receiving the BCG Vaccine at } \\
\text { birth does not have a protective } \\
\text { effect against COVID-19 }\end{array}$ \\
\hline Hamiel et al. 2020 [15] & $\chi 2$ tests & $\begin{array}{l}\text { Born from } 1979 \text { to } 1981 \text { aged } \\
\text { 39-41 years with those born from } \\
1983 \text { to } 1985 \text { aged } 35-37 \text { years (Israel) }\end{array}$ & $\begin{array}{l}\text { BCG vaccination in childhood has } \\
\text { not a protective effect against } \\
\text { COVID-19 in adulthood }\end{array}$ \\
\hline Escobar et al. 2020 [13] & $t$ test & East and West Germany (Germany) & $\begin{array}{l}\text { The average and mean COVID-19 } \\
\text { mortality rate in western German } \\
\text { states was higher than in eastern } \\
\text { states }\end{array}$ \\
\hline Kinoshita et al. 2020 [52] & $\begin{array}{l}\text { Mann-Whitney } U \text { test and } \\
\text { Spearman's rank correlation }\end{array}$ & $\begin{array}{l}\text { Annual BCG vaccine coverage } \\
\text { among the five prefectures with no } \\
\text { COVID-19 infections and the top } \\
5 \text { prefectures with the highest } \\
\text { COVID-19 prevalence and age } \\
\text { groups (Japan) }\end{array}$ & $\begin{array}{l}\text { Routine infant BCG vaccination } \\
\text { coverage in young generation had } \\
\text { a significant impact on prevention } \\
\text { of local COVID-19 spread }\end{array}$ \\
\hline Hauer et al. $2020[50]$ & Student's $t$ test & $\begin{array}{l}\text { Record morbidity and mortality of } \\
\text { SARS-CoV-2 data in formerly East } \\
\text { and West German federal states } \\
\text { (Germany) }\end{array}$ & $\begin{array}{l}\text { BCG vaccination has a } \\
\text { protective effect }\end{array}$ \\
\hline
\end{tabular}

the relation between BCG and morbidity and/or mortality of coronavirus has been analyzed using Student's $t$ test approach and suggests it as an effective vaccination [13, 50]. An RD approach is used to study the correlation between BCG vaccine and COVID-19 severity in Sweden that stated this vaccination does not have any protective effect against infection [51]. The benefit of a shift in BCG vaccinations policy was also taken to study the correlation between BCG vaccine and COVID-19 severity in Israel and Japan and two contradictions results have been reported $[15,52]$.

\section{Analysis of Subgroups}

Identification of relationships within various subgroups is the usual form of study through observational research. This type of study is applied in the papers of Table 3 to evaluate the efficacy of BCG to the reduction of COVID-19 incidence or severity. To analyze whether receiving recent $\mathrm{BCG}$ vaccines is harmless during SARS-CoV-2 prevalence, three cohorts of healthy volunteers who have either received or not received BCG in the past 5 years were compared. The majority of

Table 3 Summary of assessing the effect of BCG on COVID-19 in the study of subgroups

\begin{tabular}{|c|c|c|c|}
\hline Title & Study case & Method & Finding \\
\hline Amirlak et al. 2020 [56] & $\begin{array}{l}\text { Booster vaccinated, versus } \\
\text { unvaccinated }\end{array}$ & Fisher's exact test & $\begin{array}{l}\text { The infection rate in the unvaccinated } \\
\text { group was } 8.6 \% \text { versus } 0 \text { in the } \\
\text { booster vaccinated }\end{array}$ \\
\hline Karabay et al. 2020 [54] & $\begin{array}{l}\text { The presence of COVID-19 was } \\
\text { investigated in } 167 \text { patients } \\
\text { with BCG and } 167 \text { without BCG }\end{array}$ & $\begin{array}{l}\text { Independent Samples } t \text { test and } \\
\text { Yates correction chi-square test }\end{array}$ & $\begin{array}{l}\text { The frequency of COVID-19 in those } \\
\text { who received intravesical BCG } \\
\text { was not different from those who } \\
\text { did not }\end{array}$ \\
\hline Moorlag et al. 2020 [53] & $\begin{array}{l}\text { Three cohorts of healthy volunteers } \\
\text { who either received BCG in the last } \\
5 \text { years or did not }\end{array}$ & $\begin{array}{l}\text { Chi-square test of independence } \\
\text { for categorical variables. Wilcoxon } \\
\text { rank-sum test for continuous } \\
\text { variables. Fisher's exact test for } \\
\text { the comparison of underlying } \\
\text { conditions, employment status, } \\
\text { and the variable college degree }\end{array}$ & $\begin{array}{l}\text { BCG vaccination is not associated } \\
\text { with increased incidence of symptoms } \\
\text { during the pandemic and it might } \\
\text { be associated with a decrease in the } \\
\text { incidence of sickness during the } \\
\text { pandemic }\end{array}$ \\
\hline Samrah et al. 2020 [55] & $\begin{array}{l}\text { Among } 81 \text { patients affected, } 84 \% \\
\text { of patients reported receiving BCG } \\
\text { vaccination }\end{array}$ & $\begin{array}{l}\text { A chi-square test or Fisher's exact } \\
\text { test for categorical variables, whereas } \\
\text { continuous variables were analyzed } \\
\text { by the Student's } t \text { test or ANOVA }\end{array}$ & $\begin{array}{l}\text { More asymptomatic patients were } \\
\text { among those who received BCG }\end{array}$ \\
\hline
\end{tabular}


Table 4 Timeline of current clinical trials assessing the impact of BCG on COVID-19 [58]

\begin{tabular}{|c|c|c|c|c|c|c|c|c|c|c|c|c|c|c|c|c|c|c|c|}
\hline \multicolumn{2}{|c|}{$\begin{array}{l}\text { Estimated Study } \\
\text { Completion Date }\end{array}$} & \multirow{2}{*}{$\begin{array}{c}\text { ণิ } \\
\text { రి } \\
\text { Dec }\end{array}$} & \multicolumn{12}{|c|}{$\overline{\widetilde{N}}$} & \multicolumn{2}{|l|}{ તิ } & \multicolumn{2}{|l|}{ તิ } & \multirow[t]{2}{*}{$\begin{array}{l}\text { particip } \\
\text { ants }\end{array}$} \\
\hline \multirow{11}{*}{ 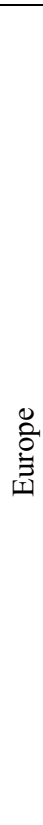 } & country & & $\begin{array}{l}\mathbf{J a} \\
\mathrm{n}\end{array}$ & Feb & Mar & $\overline{\text { Apr }}$ & May & $\begin{array}{l}\text { Ju } \\
\text { n }\end{array}$ & July & Aug & Sep & $\begin{array}{l}\text { Oc } \\
\text { t }\end{array}$ & Nov & Dec & Mar & $\begin{array}{l}\text { Oc } \\
t\end{array}$ & $\overline{\text { Apr }}$ & $\overline{\text { Aug }}$ & \\
\hline & France (Recruiting) & & & 0 & & & & & & & & & & & & & & & 1120 \\
\hline & $\begin{array}{l}\text { Netherlands (Active, } \\
\text { not recruiting) }\end{array}$ & & & & & 0 & & & & & & & & & & & & & 1500 \\
\hline & $\begin{array}{l}\text { Netherlands } \\
\text { (Recruiting) }\end{array}$ & & & & & ○ & & & & & & & & & & & & & 5200 \\
\hline & $\underline{\text { Poland (recruiting) }}$ & & & & & 0 & & & & & & & & & & & & & 1000 \\
\hline & $\begin{array}{l}\text { Netherlands (Active, } \\
\text { not recruiting) }\end{array}$ & & & & & & ○ & & & & & & & & & & & & 2014 \\
\hline & $\begin{array}{l}\text { Germany (Active, not } \\
\text { recruiting) }\end{array}$ & & & & & & 0 & & & & & & & & & & & & 59 \\
\hline & Greece (Recruiting) & & & & & & 0 & & & & & & & & & & & & 900 \\
\hline & $\begin{array}{l}\text { Denmark } \\
\text { (Recruiting) }\end{array}$ & & & & & & & & & ○ & & & & & & & & & 1500 \\
\hline & Germany (Recruiting) & & & & & & & & & & P & & & & & & & & 2038 \\
\hline & Denmark (Recruiting) & & & & & & & & & & & & & & 0 & & & & 1900 \\
\hline \multirow{4}{*}{$\sum^{\mathbb{U}}$} & $\begin{array}{ll}\text { Egypt (Not yet } \\
\text { recruiting) }\end{array}$ & 0 & & & & & & & & & & & & & & & & & 900 \\
\hline & $\begin{array}{ll}\text { South } & \text { Africa } \\
\text { (Recruiting) }\end{array}$ & & & & & 0 & & & & & & & & & & & & & 500 \\
\hline & $\begin{array}{l}\text { Guinea-Bissau } \\
\begin{array}{l}\text { (Enrolling } \\
\text { invitation) }\end{array} \text { by }\end{array}$ & & & & & & & 0 & & & & & & & & & & & 3400 \\
\hline & $\begin{array}{l}\frac{\text { Guinea-Bissau/ }}{\text { Mozambique (Not yet }} \\
\text { recruiting) }\end{array}$ & & & & & & & & & & & & & & 0 & & & & 1050 \\
\hline \multirow{7}{*}{$\frac{\mathscr{J}}{\frac{0}{\mathbb{E}}}$} & $\begin{array}{l}\text { Mexico (Active, not } \\
\text { recruiting) }\end{array}$ & & 0 & & & & & & & & & & & & & & & & 908 \\
\hline & $\underline{\text { Canada (Recruiting) }}$ & & & & & & & & ○ & & & & & & & & & & 3626 \\
\hline & $\begin{array}{ll}\text { United } & \text { States } \\
\text { (Recruiting) } & \end{array}$ & & & & & & & & & & & & 0 & & & & & & 1800 \\
\hline & $\frac{\text { United States (Not yet }}{\text { recruiting) }}$ & & & & & & & & & & & & 0 & & & & & & 2100 \\
\hline & Brazil (Recruiting) & & & & & & & & & & & & & & & n & & & 1000 \\
\hline & $\frac{\text { United States (Not yet }}{\text { recruiting) }}$ & & & & & & & & & & & & & & & & 0 & & 550 \\
\hline & Brazil (Recruiting) & & & & & & & & & & & & & & & & & 0 & 1000 \\
\hline \multirow{2}{*}{$\stackrel{\bar{\Xi}}{\overline{0}}$} & India (Recruiting) & & & & & & 0 & & & & & & & & & & & & 2175 \\
\hline & Australia (Recruiting) & & & & & & & & & & & & & & 0 & & & & 10078 \\
\hline
\end{tabular}

participants live in the provinces with the largest number of infected. Self-reported illness and symptoms indicated that in the BCG-vaccinated group, the incidence of disease was significantly smaller relative to the unvaccinated people ( $20.7 \%$ vs $31.1 \%$, crude odds ratio 0.58 , and $p<0.05$ ). A logistic regression model was used for adjustment of potential 
covariates. The results revealed an adjusted odds ratio of 0.58 $(p<0.05)$, confirming previous findings. Although the data indicated that $\mathrm{BCG}$ vaccinations could be linked with a reduction in the number of cases during the pandemic, the authors did not offer conclusions about the possible beneficial impact of BCG on coronavirus infection for reasons such as the retrospective aspects of the research in two relatively small sample groups and the possibility of selection bias. They concluded that BCG vaccinations can be safe during the pandemic and suggested randomized clinical trials to investigate the protective effects of BCG against infection [53]. In another study the incidence of COVID-19 was examined in bladder cancer patients. Patients were categorized into two groups: those patients got intravesical BCG because of their cancer and those patients that did not it as a control group. According to the results, the frequency of infection in those patients who received the intravesical vaccine was not differing from the other group [54]. To report the epidemiological, clinical, and radiological symptoms of infected patients from Jordan, a retrospective analysis was performed. In this study, BCG vaccination was also reported in $84 \%$ of patients. The results show that more asymptomatic patients had been vaccinated with $\operatorname{BCG}(p=0.017)[55]$.

\section{Clinical trials studies}

There may be complex factors that make a correlation between vaccination of BCG and decreased deaths. For instance, the genetic structure of the population or environmental factors. Well-controlled clinical trials do not suffer from selection possible and confounding factors and can provide a conclusive response to the existence of causal link between BCG vaccine and COVID-19 outcomes. In epidemic infections for which there are no effective vaccines, it is important to test the investigational vaccines rapidly and, if they are effective, utilize them in the same outbreak. Also, cases can become so uncommon in a diminishing outbreak so that a trial is no longer possible [57]. At this time, 25 clinical trials have been officially registered in various countries which two of them have been withdrawn [58]. Most designs used for BCG vaccine efficacy trials are individually randomized and their interventional mode of them is parallel. The expected completion dates of ongoing clinical trials are given in Table 4.

\section{Conclusions}

The immunogenicity and efficacy of the BCG vaccine is widely accepted as it has been used for around 100 years. Due to the large availability and low-cost of BCG, it can be considered as a good option for the creation of trained immunity against diseases. However, BCG is a vaccine that protects infants against $\mathrm{TB}$, especially in developing countries.
Furthermore, it is utilized as standard adjuvant immunotherapy to treat bladder cancer patients with high-risk non-muscle invasive cancer. Therefore, there is concern that a sudden increase in demand for this vaccine could cause imbalances in production and consumption. This highlights the necessity for careful researches.

In this study, an overview of the current studies concerning the possible effect of BCG against COVID-19 was presented. In general, three separate approaches were identified: (a) across countries studies where their epidemiological data, related to BCG policy and COVID-19 cases and/or mortalities, were collected based on public sources and analyzed statistically. (b) Studies where countries with discontinued vaccination policy were interested. Similar to the former group, epidemiological data were collected from institutional databases due to the data availability. Although these data can indicate a beneficial effect of BCG vaccinations, such researches may not provide definitive evidence of causal relationship [59]. (c) Observational studies where relationships between two subgroups were observed. In these studies, the retrospective aspect of the research in relatively small groups has the potential for introducing statistical bias in the analysis. Due to various confounding factors, most observational studies converge on a point that there would be inadequate evidence and clinical trials are required. Several clinical trials are underway in determining whether BCG could effect on COVID-19 and their results can provide a conclusive answer to this question.

Code Availability Not applicable

Authors' Contributions NB and HM did the study design and wrote the manuscript. All authors have read and approved the final manuscript.

Data Availability Not applicable

\section{Declarations}

Ethics Approval and Consent to Participate Not applicable

Consent for Publication Not applicable

Competing Interests The authors declare that they have no competing interests.

\section{References}

1. Mizumoto K, Kagaya K, Zarebski A, Chowell G. Estimating the asymptomatic proportion of coronavirus disease 2019 (COVID-19) cases on board the Diamond Princess cruise ship, Yokohama, Japan, 2020. Eurosurveillance. 2020;25(10):2000180. https://doi. org/10.2807/1560-7917.ES.2020.25.10.2000180.

2. Bentivegna E, Luciani M, Spuntarelli V, Speranza M, Guerritore L, Sentimentale A, et al. Extremely severe case of COVID-19 pneumonia recovered despite bad prognostic indicators: a didactic 
report. SN Compr Clin Med. 2020;2(8):1204-7. https://doi.org/10. 1007/s42399-020-00383-0.

3. Dong Y, Mo X, Hu Y, Qi X, Jiang F, Jiang Z, et al. Epidemiology of COVID-19 among children in China. Pediatrics. 2020;145(6): e20200702. https://doi.org/10.1542/peds.2020-0702.

4. Kuchar E, Załęski A, Wronowski M, Krankowska D, Podsiadły E, Brodaczewska K, et al. Children were less frequently infected with SARS-CoV-2 than adults during 2020 COVID-19 pandemic in Warsaw, Poland. Eur J Clin Microbiol Infect Dis. 2020:1-7. https://doi.org/10.1007/s10096-020-04038-9.

5. Brodin P. Why is COVID-19 so mild in children? Acta Paediatr. 2020;109(6):1082-3. https://doi.org/10.1111/apa.15271.

6. Bentivegna E, Sentimentale A, Luciani M, Speranza ML, Guerritore L, Martelletti P. New IgM seroconversion and positive RT-PCR test after exposure to the virus in recovered COVID-19 patient. J Med Virol. 2021;93(1):97-8. https://doi.org/10.1002/ jmv.26160.

7. Luciani M, Bentivegna E, Spuntarelli V, Lamberti PA, Cacioli G, Del Porto F, et al. Recurrent COVID-19 pneumonia in the course of chemotherapy: Consequence of a weakened immune system? J Med Virol. 2020;93:1882-4. https://doi.org/10.1002/jmv.26701.

8. Pai M, Behr MA, Dowdy D, Dheda K, Divangahi M, Boehme CC, et al. Tuberculosis. Nat Rev Dis Primers. 2016;2:16076. https://doi. org/10.1038/nrdp.2016.76.

9. Van Etten E, Stoffels K, Gysemans C, Mathieu C, Overbergh L. Regulation of vitamin D homeostasis: implications for the immune system. Nutr Rev. 2008;66(suppl_2):S125-S34. https://doi.org/10. 1111/j.1753-4887.2008.00096.x.

10. Lalor MK, Floyd S, Gorak-Stolinska P, Weir RE, Blitz R, Branson $\mathrm{K}$, et al. BCG vaccination: a role for vitamin D? PLoS One. 2011;6(1):e16709. https://doi.org/10.1371/journal.pone.0016709.

11. Moorlag S, Arts R, Van Crevel R, Netea M. Non-specific effects of $B C G$ vaccine on viral infections. Clin Microbiol Infect. 2019;25(12):1473-8. https://doi.org/10.1016/j.cmi.2019.04.020.

12. Chumakov K, Benn CS, Aaby P, Kottilil S, Gallo R. Can existing live vaccines prevent COVID-19? Science. 2020;368(6496):11878. https://doi.org/10.1126/science.abc4262.

13. Escobar LE, Molina-Cruz A, Barillas-Mury C. BCG vaccine protection from severe coronavirus disease 2019 (COVID-19). Proc Natl Acad Sci. 2020;117(30):17720-6. https://doi.org/10.1101/ 2020.05.05.20091975

14. Arlehamn CSL, Sette A, Peters B. Lack of evidence for BCG vaccine protection from severe COVID-19. Proc Natl Acad Sci. 2020;117(41):25203-4. https://doi.org/10.1073/pnas.2016733117.

15. Hamiel U, Kozer E, Youngster I. SARS-CoV-2 Rates in BCGvaccinated and unvaccinated young adults. Jama. 2020;323(22): 2340-1. https://doi.org/10.1001/jama.2020.8189.

16. Mathurin KS, Martens GW, Kornfeld H, Welsh RM. CD4 T-cellmediated heterologous immunity between mycobacteria and poxviruses. J Virol. 2009;83(8):3528-39. https://doi.org/10.1128/JVI. 02393-08.

17. Kleinnijenhuis J, Quintin J, Preijers F, Joosten LA, Ifrim DC, Saeed $\mathrm{S}$, et al. Bacille Calmette-Guerin induces NOD2-dependent nonspecific protection from reinfection via epigenetic reprogramming of monocytes. Proc Natl Acad Sci. 2012;109(43):17537-42. https:// doi.org/10.1073/pnas.1202870109.

18. Netea MG, Joosten LA, Latz E, Mills KH, Natoli G, Stunnenberg $\mathrm{HG}$, et al. Trained immunity: a program of innate immune memory in health and disease. Science. 2016;352(6284):aaf1098. https:// doi.org/10.1126/science.aaf1098.

19. Mantovani A, Netea MG. Trained innate immunity, epigenetics, and Covid-19. N Engl J Med. 2020;383(11):1078-80. https://doi. org/10.1056/NEJMcibr2011679.

20. Trunz BB, Fine P, Dye C. Effect of BCG vaccination on childhood tuberculous meningitis and miliary tuberculosis worldwide: a metaanalysis and assessment of cost-effectiveness. Lancet.
2006;367(9517):1173-80. https://doi.org/10.1016/S01406736(06)68507-3.

21. Roy A, Eisenhut M, Harris R, Rodrigues L, Sridhar S, Habermann $\mathrm{S}$, et al. Effect of BCG vaccination against Mycobacterium tuberculosis infection in children: systematic review and meta-analysis. Bmj. 2014;349:g4643. https://doi.org/10.1136/bmj.g4643.

22. Luciani M, Bentivegna E, Spuntarelli V, Lamberti PA, Guerritore L, Chiappino D, et al. Coinfection of tuberculosis pneumonia and COVID-19 in a patient vaccinated with Bacille Calmette-Guerin (BCG): Case report. SN Compr Clin Med. 2020;2(11):2419-22. https://doi.org/10.1007/s42399-020-00601-9.

23. Aaby P, Roth A, Ravn H, Napirna BM, Rodrigues A, Lisse IM, et al. Randomized trial of BCG vaccination at birth to low-birthweight children: beneficial nonspecific effects in the neonatal period? J Infect Dis. 2011;204(2):245-52. https://doi.org/10.1093/ infdis/jir240.

24. Wardhana DE, Sultana A, Mandang V, Jim E. The efficacy of Bacillus Calmette-Guerin vaccinations for the prevention of acute upper respiratory tract infection in the elderly. Acta Med Indones. 2011:43(3):185-90.

25. Leentjens J, Kox M, Stokman R, Gerretsen J, Diavatopoulos DA, van Crevel R, et al. BCG vaccination enhances the immunogenicity of subsequent influenza vaccination in healthy volunteers: a randomized, placebo-controlled pilot study. J Infect Dis. 2015;212(12):1930-8. https://doi.org/10.1093/infdis/jiv332.

26. Arts RJ, Moorlag SJ, Novakovic B, Li Y, Wang S-Y, Oosting M, et al. BCG vaccination protects against experimental viral infection in humans through the induction of cytokines associated with trained immunity. Cell Host Microbe. 2018;23(1):89-100. e5. https://doi.org/10.1016/j.chom.2017.12.010.

27. Usher NT, Chang S, Howard RS, Martinez A, Harrison LH, Santosham M, et al. Association of BCG vaccination in childhood with subsequent cancer diagnoses: a 60-year follow-up of a clinical trial. JAMA Netw Open. 2019;2(9):e1912014-e. https://doi.org/10. 1001/jamanetworkopen.2019.12014.

28. Guallar-Garrido S, Julián E. Bacillus Calmette-Guérin (BCG) therapy for bladder cancer: an update. ImmunoTargets Ther. 2020;9:111. https://doi.org/10.2147/ITT.S202006.

29. Kühtreiber WM, Faustman DL. BCG therapy for type 1 diabetes: restoration of balanced immunity and metabolism. Trends Endocrinol Metab. 2019;30(2):80-92. https://doi.org/10.1016/j. tem.2018.11.006.

30. Sudre CH, Lee K, Lochlainn MN, Varsavsky T, Murray B, Graham MS, et al. Symptom clusters in Covid19: A potential clinical prediction tool from the COVID Symptom study app. MedRxiv. 2020. https://doi.org/10.1101/2020.06.12.20129056.

31. Benn CS, Fisker AB, Whittle HC, Aaby P. Revaccination with live attenuated vaccines confer additional beneficial nonspecific effects on overall survival: a review. EBioMedicine. 2016;10:312-7. https://doi.org/10.1016/j.ebiom.2016.07.016.

32. Biot C, Rentsch CA, Gsponer JR, Birkhäuser FD, JusforguesSaklani H, Lemaître F, et al. Preexisting BCG-specific T cells improve intravesical immunotherapy for bladder cancer. Sci Transl Med. 2012;4(137):137ra72-ra72. https://doi.org/10.1126/ scitranslmed.3003586.

33. Organization WH. WHO. World Health organization global tuberculosis report. World Health Organization; 2017.

34. Nemes E, Geldenhuys H, Rozot V, Rutkowski KT, Ratangee F, Bilek N, et al. Prevention of M. tuberculosis infection with H4: IC31 vaccine or BCG revaccination. N Engl J Med. 2018;379(2): 138-49. https://doi.org/10.1056/NEJMoa1714021.

35. Kristensen I, Fine P, Aaby P, Jensen H. Routine vaccinations and child survival: follow up study in Guinea-Bissau, West AfricaCommentary: an unexpected finding that needs confirmation or rejection. Bmj. 2000;321(7274):1435-8. https://doi.org/10.1136/ bmj.321.7274.1435. 
36. Roth AE, Benn CS, Ravn H, Rodrigues A, Lisse IM, Yazdanbakhsh M, et al. Effect of revaccination with BCG in early childhood on mortality: randomised trial in Guinea-Bissau. Bmj. 2010;340:c671. https://doi.org/10.1136/bmj.c671.

37. Dourado I, Rios M, Pereira S, Cunha S, Ichihara M, Goes J, et al. Rates of adverse reactions to first and second doses of BCG vaccination: results of a large community trial in Brazilian schoolchildren. Int J Tuberc Lung Dis. 2003;7(4):399-402.

38. Giamarellos-Bourboulis EJ, Tsilika M, Moorlag S, Antonakos N, Kotsaki A, Domínguez-Andrés J, et al. ACTIVATE: Randomized clinical trial of BCG vaccination against infection in the elderly. Cell. 2020;183(2):315-23. e9. https://doi.org/10.1016/j.cell.2020. 08.051 .

39. Wickramasinghe D, Wickramasinghe N, Kamburugamuwa S A, Arambepola C, Samarasekera DN. Correlation between immunity from BCG and the morbidity and mortality of COVID-19. Tropical Diseases, Travel Medicine and Vaccines. 2020;6. https://doi.org/ 10.1186/s40794-020-00117-z.

40. Kumar A, Misra S, Verma V, Vishwakarma RK, Kamal VK, Nath $\mathrm{M}$, et al. Global impact of environmental temperature and BCG vaccination coverage on the transmissibility and fatality rate of COVID-19. PLoS One. 2020;15(10):e0240710. https://doi.org/10. 1371/journal.pone.0240710.

41. Klinger D, Blass I, Rappoport N, Linial M. Significantly improved COVID-19 outcomes in countries with higher BCG vaccination coverage: A multivariable analysis. Vaccines. 2020;8(3):378. https://doi.org/10.3390/vaccines8030378.

42. Berg MK, Yu Q, Salvador CE, Melani I, Kitayama S. Mandated Bacillus Calmette-Guérin (BCG) vaccination predicts flattened curves for the spread of COVID-19. Sci Adv. 2020;6:eabc1463. https://doi.org/10.1126/sciadv.abc1463.

43. Joy M, Malavika B, Asirvatham ES, Sudarsanam TD, Jeyaseelan L. Is BCG associated with reduced incidence of COVID-19? A metaregression of global data from 160 countries. Clinical Epidemiology and Global Health. 2020. https://doi.org/10.1016/j. cegh.2020.08.015.

44. Miller A, Reandelar MJ, Fasciglione K, Roumenova V, Li Y, Otazu GH. Correlation between universal BCG vaccination policy and reduced morbidity and mortality for COVID-19: an epidemiological study. MedRxiv. 2020. https://doi.org/10.1101/2020.03.24. 20042937.

45. Szigeti R, Kellermayer D, Trakimas G, Kellermayer R. BCG epidemiology supports its protection against COVID-19? A word of caution. PLoS One. 2020;15(10):e0240203. https://doi.org/10. 1371/journal.pone.0240203.

46. Wassenaar TM, Buzard GS, Newman DJ. BCG vaccination early in life does not improve COVID-19 outcome of elderly populations, based on nationally reported data. Letters in Applied Microbiology. 2020;71(5):498-505. https://doi.org/10.1111/lam.13365.

47. Hensel J, McAndrews KM, McGrail DJ, Dowlatshahi DP, LeBleu VS, Kalluri R. Protection against SARS-CoV-2 by BCG vaccination is not supported by epidemiological analyses. Sci Rep. 2020;10(1):1-9. https://doi.org/10.1038/s41598-020-75491-x.

48. Matsuura H, Fukui M, Kawaguchi K. Does TB vaccination reduce covid-19 infection?: no evidence from a regression discontinuity and difference-in-differences analysis. medRxiv. 2020. https://doi. org/10.1101/2020.04.13.20064287.

\section{Web References}

49. https://mapchart.net/world.html. December 4, 2020.

50. Hauer J, Fischer U, Auer F, Borkhardt A. Regional BCG vaccination policy in former East-and West Germany may impact on both severity of SARS-CoV-2 and incidence of childhood leukemia. Leukemia. 2020;34(8):2217-9. https://doi.org/10.1038/s41375020-0871-4.

51. de Chaisemartin C, de Chaisemartin L. Bacille Calmette-Guérin Vaccination in Infancy Does Not Protect Against Coronavirus Disease 2019 (COVID-19): evidence From a Natural Experiment in Sweden. Clin Infect Dis. 2020. https://doi.org/10.1093/cid/ ciaa1223.

52. Kinoshita M, Tanaka M. Impact of routine infant $B C G$ vaccination in young generation on prevention of local COVID-19 spread in Japan. J Infect. 2020;81(4):625-33. https://doi.org/10.1016/j.jinf. 2020.08.013.

53. Moorlag SJ, van Deuren RC, van Werkhoven CH, Jaeger M, Debisarun P, Taks E, et al. Safety and COVID-19 symptoms in individuals recently vaccinated with BCG: a retrospective cohort study. Cell Rep Med. 2020;1(5):100073. https://doi.org/10.1016/j. xcrm.2020.100073.

54. Karabay O, Köse O, Tocoglu A, Uysal B, Dheir H, Yaylaci S, et al. Investigation of the frequency of COVID-19 in patients treated with intravesical BCG. Rev Assoc Med Bras. 2020;66:91-5. https://doi. org/10.1590/1806-9282.66.s2.91.

55. Samrah SM, Al-Mistarehi A-HW, Ibnian AM, Raffee LA, Momany SM, Al-Ali M, et al. COVID-19 outbreak in Jordan: Epidemiological features, clinical characteristics, and laboratory findings. Ann Med Surg. 2020;57:103-8. https://doi.org/10.1016/ j.amsu.2020.07.020.

56. Amirlak I, Haddad R, Hardy JD, Khaled NS, Chung MH, Amirlak B. Effectiveness of booster BCG vaccination in preventing Covid19 infection. medRxiv. 2020. https://doi.org/10.1101/2020.08.10. 20172288

57. Kahn R, Rid A, Smith PG, Eyal N, Lipsitch M. Choices in vaccine trial design in epidemics of emerging infections. PLoS Med. 2018;15(8):e1002632. https://doi.org/10.1371/journal.pmed. 1002632.

58. https://clinicaltrials.gov/ct2/results?cond=Covid19\&term $=\mathrm{BCG}+$ vaccination $\&$ cntry $=\&$ state $=\&$ city $=\&$ dist $=$. December 10, 2020.

59. Gopalaswamy R, Ganesan N, Velmurugan K, Aravindhan V, Subbian S. The strange case of BCG and COVID-19: The verdict is still up in the air. Vaccines. 2020;8(4):612. https://doi.org/10. 3390/vaccines 8040612 .

Publisher's Note Springer Nature remains neutral with regard to jurisdictional claims in published maps and institutional affiliations. 